УДК 338.45:622.33(571.63) (09)

DOI dx.doi.org/10.24866/1997-2857/2020-3/106-118

А.В. Маклюков, О.К. Павленко*

\title{
ТЕХНИЧЕСКОЕ ПЕРЕОСНАЩЕНИЕ ПРЕДПРИЯТИЙ УГОЛЬНОЙ ПРОМЫШЛЕННОСТИ ПРИМОРЬЯ В ГОДЫ ИНДУСТРИАЛИЗАЦИИ
}

\begin{abstract}
В статье рассматриваются исторические аспекты процесса технического переоснащения угольной отрасли Приморья в 1930-е гг., выявляются предпосылки, условия и трудности перехода угольных предприятий региона на новую техническую основу. На смену полукустарным дореволюционным шахтам, основанным на ручном труде и паровых машинах, пришли современные технически оснащенные механизированные угледобывающие предприятия, работающие на машинах с электрическим приводом, однако процесс технического переоснащения шахт Приморья под влиянием различных факторов происходил медленнее, чем в других районах страны. Несмотря на это, как заключают авторы, приморские шахты в годы индустриализации стали главной топливной базой для развития электроэнергетики, индустрии и оборонной промышленности Дальнего Востока.
\end{abstract}

Ключевые слова: угольная промышленность, механизация, электрификация, машинизация, индустриализация, Приморье, Дальний Восток

Technical re-equipment of coal industry enterprises in Primorye during industrialization. ALEKSEY V. MAKLYUKOV (Institute of History, Archaeology and Ethnography of Peoples of Far East, Far Eastern Branch of Russian Academy of Sciences), OLEG K. PAVLENKO (Far Eastern Federal University)

The article examines the history of the technical re-equipment of the coal industry in Primorye in the 1930s, identifying the background, conditions and difficulties of coal enterprises' transition to new technical base. The pre-revolutionary semi-artisan mines based on manual labor and steam engines were replaced by modern technically equipped mechanized coal mining enterprises, however, the process of technical re-equipment here went slower than in other regions of the Soviet Union due to the influence of various factors. Nevertheless, as the authors conclude, during industrialization the coal mines of Primorye became the main fuel base for the development of power generation, industry and defense sector in the Soviet Far East.

Keywords: coal industry, mechanization, electrification, industrialization, Primorye, Soviet Far East

* МАКЛЮКОВ Алексей Владимирович, кандидат исторических наук, заведующий Отделом истории Дальнего Востока России Института истории, археологии и этнографии народов Дальнего Востока Дальневосточного отделения РАН.

E-mail: alekseymaklyukov@yandex.ru

ПАВЛЕНКО Олег Константинович, магистрант Департамента истории и археологии Школы искусств и гуманитарных наук Дальневосточного федерального университета.

E-mail: pavlenko.ok@students.dvfu.ru

(C) Маклюков А.В., Павленко О.К., 2020 
Период индустриализации в СССР - это время радикального обновления отечественного промышленного производства на базе новейших достижений науки, технологий и техники. Угольная промышленность являлась главной энергетической базой, на основе которой формировалась тяжелая индустрия, велось промышленное строительство и шло наращивание оборонно-экономического потенциала страны. На Дальнем Востоке предприятия угольной отрасли концентрировалась в основном в южной части Приморья. Приморские шахты первыми в регионе прошли путь глубокой технической перестройки для обеспечения промышленных потребностей в топливе и укрепления оборонного потенциала дальневосточных рубежей страны.

Несмотря на то, что историографическая база по истории угольной промышленности Дальнего Востока в период индустриализации достаточно объемна $[1 ; 2 ; 4 ; 5 ; 6 ; 7 ; 8 ; 10 ; 13$; $14 ; 15 ; 16]$, проблемы технического переоснащения предприятий угольной отрасли в рассматриваемый период остаются изученными недостаточно. Советские и современные авторы не ставили перед собой задачу освещения процесса технической перестройки угледобывающего производства, рассматривали эту тему лишь фрагментарно на фоне других сюжетов, многие приведенные ими факты требуют уточнения, а концепции и выводы - пересмотра.

В данной статье авторы, фокусируя внимание на исторических аспектах процесса технического переоснащения угольной отрасли Приморья в период индустриализации, ставят перед собой задачу выявить и проанализировать предпосылки, условия, трудности и региональную специфику обновления производственных фондов шахт, а также раскрыть значение использования новых машин и техники в развития угледобывающего производства.

Источниковой базой исследования является неопубликованные архивные материалы, выявленных в фондах федеральных и региональных архивов. Основными видами документов, изученных в данных архивах, являются аналитические и докладные записки, справки, статистические материалы, годовые отчеты угольных предприятий и трестов, планы, постановления правительства и региональных органов власти, касающиеся развития угольной отрасли Приморья в исследуемый период.

Угольная промышленность Приморья как самостоятельная отрасль экономики сформиро- валась на рубеже XIX-XX вв. В это же время начался процесс механизации производства, на шахтах появились паровые машины, выполняющие подъемные функции, строились электростанции для освещения и моторной нагрузки - насосов, вентиляторов, станочного оборудования, элеваторов, конвейерных лент. Среди десятка приморских угольных предприятий самыми крупными и технически оснащенными являлись Сучанские казенные копи. Однако многие силовые процессы, такие как зарубка и откатка угля, производилась вручную или конной тягой. На приморских шахтах устанавливалось морально устаревшее паровое и электрическое оборудование, по техническому уровню они значительно отставали от сибирских и донбасских шахт [11, с. $37 ; 12$, с. 98].

Проблемы технического переоснащения Сучанских копей остро проявили себя в годы Гражданской войны, когда предприятие полностью лишилось государственных субсидий и перешло на самоокупаемость. Старые и малопроизводительные машины вышли из строя, предприятие до $60-70 \%$ добываемого угля расходовало на собственные производственные нужды, что делало его работу полностью нерентабельной. В декабре 1922 г. - июне 1923 г. в планово-хозяйственные органы Дальневосточной области обращался представитель американской фирмы Asia Development Co. Ltd Г.Ф. Томстфор, который предлагал за концессию осуществить полную реконструкцию Сучанских копей по американской системе с внедрением новейших импортных машин. Начальник Приморского горного округа инженер В.С. Пак, ранее управлявший Сучанским предприятием, посчитал данное предложение «возможным» и предлагал вступить в переговоры. Под давлением центра дальневосточные власти отказались от этого предложения (Российский государственный исторический архив Дальнего Востока, далее - РГИА ДВ. Ф. Р-2. Оп. 1. Д. 160. Л. 145-160).

В конце 1922 г. - начале 1923 г. Дальневосточная область постепенно включилась в систему народного хозяйства СССР. Мероприятия, проводимые советскими властями в отношении угольной отрасли региона, приобрели характер целенаправленной и продуманной политики, в рамках которой как в центре, так и на местах осознавалось значение угледобычи в развитии дальневосточной экономики. Происходили восстановление и национализация наиболее круп- 
ных и перспективных угольных месторождений (Сучанских, Артемовских и Липовецких шахт). 1 октября 1925 г. указом Президиума ВСНХ СССР создан трест «Примуголь», объединивший под свои началом все угледобывающие предприятия Приморья [3, с. 144].

Помимо совершенствования системы управления угольной отрасли встал вопрос о техническом обновлении шахтных фондов. 10 ноября 1925 г. Дальневосточное экономическое совещание (Дальэкосо) поставило вопрос о необходимости перехода самых крупных Сучанских копей с паровой на электрическую энергию, т.е. технической модернизации (Государственный архив Хабаровского края, далее - ГАХК. Ф. Р-353. Оп. 4. Д. 4. Л. 28; РГИА ДВ. Ф. Р-3. Оп. 2. Д. 28. Л. 209).

Следует отметить, что к середине 1920-х гг. появились условия для формирования научно-технической базы модернизации угольной промышленности Приморья. Гражданская война привела к миграции на восток страны преподавателей и студентов центральных технических вузов, других квалифицированных специалистов. В апреле 1920 г. открылся Владивостокский политехнический институт, факультеты которого вошли в состав Государственного Дальневосточного университета, являющегося в те годы главным региональным научным центром. Созданная при техническом факультете вуза кафедра тепловой механики проводила исследования на угольных предприятиях края. В 1924-1925 гг. профессор кафедры В.П. Вологдин и доцент В.А. Кравцов обследовали Артемовские и Сучанские копи. Они разработали проекты Артемовской районной электростанции (ГРЭС) и Сучанской центральной электростанции (ЦЭС), которые представили комиссии по электрификации Приморья, Дальэкосо и Госплану СССР (РГИА ДВ. Ф. Р-3. Оп. 1. Д. 639. Л. 37, 13; ГАХК. Ф. Р-1151. Оп. 1. Д. 4. Л. 50).

Техническая модернизация угольной промышленности Приморья была возможна только при активном участии государства, способного оказать финансовое и организационно-техническое содействие. Центр до конца 1920-х гг. не мог предоставить экономической помощи Дальнему Востоку, поэтому местным властям приходилось самостоятельно изыскивать средства на поддержание и экстенсивное развитие угольной отрасли, используя дореволюционный потенциал. В 1926 г. оборудование самых крупных Сучанских копей состояло из 27 паровых котлов, 23 паровых машин, 14 паровых насосов, 2 компрессоров, 4 электростанций обслуживающих 26 электромоторов. Предприятие топталось на месте и не могло выйти на новый производственный уровень по добыче угля (РИГА ДВ. Ф. Р-37. Оп. 1. Д. 50. Л. 39). Только переход на современную технологию добычи угля механизированным способом позволял увеличить производственные мощности предприятий и обеспечить региональную экономику топливом.

В апреле 1929 г. ЦК ВКП(б) принял специальное решение об ускорении социалистического строительства в дальневосточном регионе, а год спустя, в феврале 1930 г., ВЦИК и СНК РСФСР обязали Госплан РСФСР создать условия для резкого увеличения удельного веса края в промышленном производстве СССР. В этом же году были приняты постановления ВЦИК и Политбюро ЦК ВКП(б) об экономическом развитии Дальнего Востока в условиях усиливающейся военной угрозы со стороны Японии [5, c. 151]. В 1929 г. создан Дальневосточный государственный трест угольной промышленности ВСНХ СССР «Дальуголь», объединивший все угольные предприятия региона. «Дальуглю» в первый год отпускалось 35 млн. руб. для строительства новых и реконструкции старых шахт. Так как до 80\% региональной добычи угля давало Южное Приморье, львиная доля средств пошла на развитие Сучанских и Артемовских копей [6, с. 34-35].

Финансовые вливания в техническое перевооружение угольной промышленность Приморья были обусловлены тем колоссальным значением, которое она приобрела для подъема экономики, индустриализации и укрепления обороноспособности Дальнего Востока. Сучанские копи имели самое высокое качество добываемых углей в дальневосточном регионе, только здесь вырабатывался кокс - топливо для плавки, обеспечивающее литейное производство предприятий цветной металлургии, металлообрабатывающих и машиностроительных заводов Дальсельмаш и Дальзавод. Поставляемые Сучаном угли шли на производство цемента, обогащенные угли - на оборонное производство и нужды Тихоокеанского флота. Развитие электроэнергетики и транспорта также требовало резкого увеличения добычи местных углей (Государственный архив Российской Федерации, далее - ГАРФ. Ф. Р-5446. Оп. 15а. Д. 596. Л. 
68; Государственный архив Приморского края, далее - ГАПК. Ф. Р-498. Оп. 2. Д. 17. Л. 6).

В СССР крупнейшими центрами машиностроения, обеспечивающими предприятия всех угольных трестов страны, являлись заводы Донбасса - Горловский, Сталинский и Торецкий. Они производили горные машины, основное технологическое оборудование и комплектующие. В годы первой пятилетки огромную роль в техническом обновлении промышленных предприятий СССР сыграли импортные поставки машин и техники из США, Англии и Германии. Внутреннее машиностроение еще не имело возможностей для полного удовлетворения потребностей промышленности страны, в том числе угольной. До 1931-1934 гг. в СССР не производились транспортеры, горные комбайны, отбойные молотки и другая техника [11, с. 38].

В 1929 г. трест «Дальуголь» сделал первый крупный заказ у Горловского и Сталинского заводов для Сучанских копей: были заказаны мощные электронасосы, шахтовые лебедки и моторы разной мощности. Также у американской фирмы «Worthington» заказали два стационарных компрессора. В 1930 г. для Артемовских копей у Торецкого завода приобрели два электровоза троллейбусного типа грузоподъемностью 4,5 т. В том же году на шахте № 3-бис подготовили штреки и построили конвертерную подстанцию для внедрения первой на Дальнем Востоке электровозной откатки угля (РГИА ДВ. Ф. Р-2456. Оп. 1. Д. 8. Л. 2; Д. 3. Л. 155, 160).

Ключевым фактором, обусловившим техническую перестройку угольной отрасли Приморья, стала новая электроэнергетическая база предприятий, в развитие которой вкладывались огромные средства. В 1928-1931 гг. построена первая очередь Сучанской ЦЭС (2 000 кВТ) стоимостью 484 тыс. руб. В 1932 г. Главэнерго утвердило смету в 5,7 млн. руб. на строительство второй очереди станции на 5000 кВт. Крупнейшим объектом энергетики в 1932-1937 гг. стала Артемовская ГРЭС мощностью 24000 кВт, в строительство которой вложили 104,7 млн. руб. В 1936-1938 гг. построили линию передач 28 км от ГРЭС для энергообеспечения Тавричанских угольных копей $[9$, с. $99,105,130]$. Таким образом, за годы индустриализации энергообеспечение угольной отрасли Приморья качественно изменилась.

Первые импортные машины и техника поступили на угольные предприятия Приморье в 1931 г. На шахтах № 2 и № 10 Сучана в сен- тябре 1931 г. установили два электрических стационарных компрессора «Worthington» производительностью по 38 куб. м. сжатого воздуха. Тогда же из Германии привезли первую партию пневматических отбойных молотков механических ручных инструментов ударного действия для отбойки угля. Приглашенные специалисты из Германии подключи молотки к компрессорам, обучили сучанских забойщиков работе. Внедрение механизированного способа отбойки угля в значительной степени повысило производительность труда забойщиков. К октябрю 1931 г. на сучанских шахтах работало уже 75 молотков. В подземных выработках Сучана помимо отбойных молотков появились другие технические новинки - электрические вентиляторы, лебедки, скреперы, конвейеры (Российский государственный архив экономики, далее - РГАЭ. Ф. 8072. Оп. 1. Д. 11. Л. 60; ГАПК. Ф. Р-1197. ОП. 1. Д. 4. Л. 68, 68а).

С самого начала технического переоснащения угольные предприятия Приморья столкнулись с проблемой, связанной с несвоевременной и некомплектной поставкой заказанного оборудования с заводов Донбасса. Первые отечественные машины поступили в регион только в начале 1932 г. Проблема была связана, с одной стороны, с перегруженностью «приоритетными» заказами самих донецких заводов, а с другой - со значительной отдаленностью от них шахт Приморья и транспортными сложностями, которые приводили к тому, что заказы находились в пути по нескольку месяцев. Так, в марте 1932 г. без токоприемников и других элементов поступили насосы Горловского завода на шахты Сучана, из-за чего их долго не могли ввести в работу (РГАЭ. Ф. 8072. ОП. 1. Д. 11. Л. 60). В октябре 1932 г. на шахте № 10 Сучана после получения всех частей запустили в эксплуатацию первую врубовую машину Горловского завода, в результате чего увеличили механизированную добыча угля до 51,5\% (ГАПК. Ф. Р-183. Оп. 4. Д. 6. Л. 3).

Предприятия угольной отрасли Приморья, как и в дореволюционное время, по-прежнему зачастую обеспечивались морально устаревшими и демонтированными машинами сибирских и донецких шахт, машинами, которые подлежали списанию. В 1932 г. «Дальуголь» получил с Донбасса полуразобранную паровую подъемную машину 300 л.с., в итоге она не использовалась. В том же году из Донбасса и Кузбасса поступили еще две рабочие подъемные машины 
по 250 л.с. каждая, которые установили на шахте № 10-бис и № 5 Сучана. В итоге качественно изменить техническое состояние шахтных подъемов тресту «Дальуголь» до конца первой пятилетки так и не удалось (ГАПК. Ф. Р-1197. Оп. 1 Д. 4. Л. 22).

Центральные и местные партийно-хозяйственные органы уделяли внимание не только вопросам технического переоснащения производства, но и улучшению условий труда шахтеров, в частности, рационализации подземного электрического освещения. В 1932 г. на шахте № 2 Сучана впервые на Дальнем Востоке стали использоваться шахтовые аккумуляторные лампочки. В 1933 г. по поручению Наркомтруда РСФСР Управление научно-исследовательских учреждений специально разработало для условий Сучана и Артема технический проект использования искусственного освещения для ведения подземных работ, который успешно реализовался (ГАРФ. Ф. А-390. Оп. 17. Д. 137. Л. 1-6).

Появление новых машин и техники на шахтах Приморья потребовало специальной подготовки кадров и обучения шахтеров новым профессиям. В 1931 г. на Сучане создается Горнопромышленное училище, которое за первый год подготовило 794 специалиста. В 1932 г. на базе училища открывается Горный техникум единственный на Дальнем Востоке техникум горного профиля. В то же время возникло немало проблем, связанных с недостатком учебных помещений и материалов, общежитий для обучающихся, отсутствием преподавательских кадров для проведения занятий. Тем не менее, на Сучане постепенно удалось наладить систему подготовки среднетехнических кадров и обеспечить ими региональные угольные предприятия (ГАПК. Ф. Р-498. Оп. 2. Д. 22. Л. 26, 26об.).

1 декабря 1932 г. Президиум Далькрайисполкома принял постановление об организации на шахтах Артема и Сучана шестимесячных курсов по подготовке машинистов врубовых машин, бурильщиков, электриков и машинистов подъемных машин без отрыва от производства. Также, согласно документу, на шахтах началась организация годичных школ по подготовке монтеров и электромонтеров, электрослесарей, машинистов электровозов. Первые годичные курсы подготовки электромонтеров, электрослесарей и электриков открылись на базе Сучанской ЦЭС (ГАПК. Ф. Р-1197. Оп. 1. Д. 9. Л. 180; Ф. Р-34. Оп. 3. Д. 2. Л. 4).
К концу первой пятилетки технический уровень предприятий угольной промышленности Приморья качественно изменился. На Сучане зарубка и отбойка угля осуществлялись врубовой машиной и отбойными молотками (к 1933 г. их насчитывалось 135), в Артеме выемка в очистных и подготовительных работах выполнялась с помощью электробуров, доставка угля - конвейерами и ленточными транспортерами, откатка - электровозами троллейбусного типа. Росла производительность труда, которая к 1933 г. составляла по тресту «Дальуголь» 12,5 т угля в день. Средняя производительность отбойного молотка была выше плановой и составляла 167,7 т в месяц (ГАПК. Ф. Р-498. Оп. 2. Д. 22. Л. 14об., 16; Ф. Р-183. Оп. 4. Д. 6. Л. 3, 5).

За годы первой пятилетки шахтеры Приморья увеличили производство угля в 1,65 раза. В 1932 г. угольные предприятия края добыли 1693 тыс. т, прирост по сравнению с 1928 г. составлял $170 \%$. Однако угольная отрасль региона не смогла ликвидировать топливного дефицита. Несмотря на ежегодные приросты добычи угля, планы не выполнялись, а себестоимость угля в 1932 г. против 1928-1929 гг. составляла по «Дальуглю» 245\%. Главными причинами срыва производственной программы были затягивание сроков строительства отдельных шахт и все еще низкий уровень механизации угольных предприятий [14, с. 25].

На пути к техническому прогрессу в угольной промышленности страны стояло немало преград. В аналитической справке Госплана СССР от 20 декабря 1932 г., посвященной итогам реконструкции отрасли за первую пятилетку, отмечалось, что механизация не дала ожидаемого экономического эффекта. Выделялись три главные проблемы технической перестройки угольных шахт страны. Первая заключалась в разрыве уровня механизации отдельных звеньев производственного процесса. Так, зарубка, отбойка и доставка угля до главного штрека подлежали механизации, а все остальные процессы - откатка, погрузка, подготовительные и другие тяжелые работы - по-прежнему выполнялись вручную. Вторая проблема - отсутствие достаточного опыта освоения отдельных механизмов и процессов работ. «Наша механизация угля насчитывает опыт каких-нибудь 5 лет, в то время как Америка - 40 лет, Англия - 30 лет», отмечалось в документе. И, наконец, третья проблема - слабая организация труда и дисци- 
плины, низкая квалификация рабочих кадров (РГАЭ. Ф. 4372. ОП. 30. Д. 901. Л. 67, 71).

Кроме того, на приморских предприятиях зачастую наблюдалось и консервативное отношение шахтеров к новой внедряемой технике, отсутствовала специальная система стимулирования их труда, расценки за ручную добычу и добычу отбойным молотком оставались одинаковыми (ГАПК. Ф. Р-1197. ОП. 1 Д. 4. Л. 68).

Накопившиеся проблемы в развитии угольной промышленности страны предстояло решить в годы второй пятилетки. В 1933-1937 гг. советское правительство на промышленное развитие в восточных районах СССР планировало затратить 50\% всех капиталовложений, ассигнованных на новое строительство. Выступая на XVII съезде ВКП(б) в конце января 1934 г., председатель Госплана СССР В.В. Куйбышев подчеркнул: «Огромное промышленное развитие ДВК ставит ряд крупнейших проблем, требующих своего разрешения во втором пятилетии... Развитие восточных районов получит мощную поддержку со стороны наших старых промышленных центров, являвшихся боевой базой для технического перевооружения новых районов». Угольной промышленности региона уделялось особое внимание, ставилась задача по завершению ее технического переоснащения [5, с. 154].

В начале 1933 г. началась реорганизация треста «Дальуголь», который разделили на два треста «Дальуголь» и «Трансуголь». 4 ноября 1933 г. Политбюро ЦК ВКП(б) приняло решение о создании в системе Наркомата путей сообщения треста «Дальтрансуголь» на базе Артемовских и Сучанских копей с центром управления в г. Владивосток (Российский государственный архив социально-политической истории, далее - РГАСПИ. Ф. 17. ОП. 3. Д. 930. Л. 68).

Реорганизация треста, передача его активов и структуры управления другому наркомату (до 1938 г.) негативно отразились на обеспечении приморских шахт новейшим оборудованием и решении вопросов механизации, машинизации и электрификации производства. Так, в мае 1933 г. «Дальуголь» получил от Кировского завода новую турбину 3000 кВт для Сучанской ЦЭС и заключил договор на ее монтаж с трестом «Коммунэнергострой». Переход в конце года Сучанских копей в ведомство Наркомата путей сообщения аннулировал раннее заключенные договоренности, турбина несколько лет пролежала на месте без всякого использования, что создало угрозу срыва энергообеспечения предприятия, планов по внедрению механизации и добычи угля (ГАРФ. Ф. Р-5446. Оп. 15a. Д. 596. Л. 2).

Техническое переоснащение угольных шахт Приморья во второй пятилетке развернулось в условиях жесткого дефицита электроэнергии, отсутствия собственной ремонтно-технической базы и нехватки квалифицированных кадров. Партийно-хозяйственные органы, руководство наркомата и треста, принимая решения по оснащению новыми машинами приморских шахт, зачастую не учитывали их специфику и производственно-технические возможности. Сложные геологические условия угольных месторождений Приморья не позволяли широко использовать тяжелую механизацию, как на шахтах Донбасса и Сибири. Тем не менее, именно во второй пятилетке Приморье, как и все угледобывающие районы страны, получило огромное количество самых разнообразных машин и техники отечественного производства.

В 1934 г. на шахте № 10 Сучана местная парторганизация начала борьбу за внедрение механизированной откатки угля. В октябре того же года на шахте построили электровозное депо, при этом сами отечественные электровозы Торецкого завода марки АР-113 доставили и установили лишь в 1938 г. В связи с трудными геологическими условиями угольного бассейна возможность их применения в дальнейшем была ограниченной. В 1936-1937 гг. на новой шахте № 20 установили дорогостоящую (330,4 тыс. руб.) электрическую скиповую подъемную машину мощностью 410 кВт, однако она не использовалась из-за нехватки электроэнергии. Вместо нее работала старая паровая американская машина «John Wood» 150 л.с. K 1938 г. на Сучане было установлено 325 моторов различных машин суммарной мощностью 8310 кВт, в то время как ЦЭС могла выдать не более 5000 кВт, т.е. спрос на электроэнергию значительно превышал возможности ее выработки на предприятии. Поэтому значительная часть новых машин и техники находилась в простое (РГАСПИ. Ф. 17. ОП. 21. Д. 3650. Л. 150; ГАРФ. Ф. А-374. ОП. 15. Д. 2090. Л. 129; ГАПК. Ф. Р-498. Оп. 2. Д. 218. Л. 69).

С 1935 г. на шахтах Артема началось усиление механизированной добычи угля за счет применения электросверл и первых врубовых машин. Однако тяжелые врубовые машины не получили широкого применения по причине ра- 
нее разработанной и применявшейся в данных условиях системы разработки короткими столбами, при которой машины были практически бесполезны. Затруднения с внедрением тяжелых машин вызвали отказ шахт Артема от них и возвращение к старому, более испытанному способу работы - взрывчатыми веществами. Тем не менее, именно предприятия Артема удалось глубоко механизировать благодаря вводу в строй в 1937 г. Артемовской ГРЭС, которая могла обеспечить электроэнергией мощные и современные машины. Широкое внедрение механизации потребовало изменения способов доставки угля из лавы на откаточный штрек, поэтому на шахтах установили качающиеся конвейеры «ДК-15» и «ДК-5» и ленточные транспортеры. В 1937 г. на шахтах Артема работало уже 1150 моторов различных машин суммарной мощностью 12718 кВт. К 1938 г. на самой крупной шахте № 3-ц пустили 6 электровозов АР-113, скиповую подъемную машину 520 кВт, подъемную клетевую машину 165 кВт. Впервые на Дальнем Востоке для улучшения работы и контроля за новыми машинами шахты Артема обеспечили диспетчерскими камерами с электросчетчиками простоя и счетчиками, регистрирующими нагрузку (РГАЭ. Ф. 1562. Оп. 313. Д. 113. Л. 96; ГАРФ. Ф. А-374. Оп. 15. Д. 2090. Л. 129; ГАПК. Ф. Р-498. Оп. 2. Д. 170. Л. 47, 49).

Техническое переоснащение шахт Приморья привело к увеличению количества разнообразных машин и механизмов, для обслуживания которых, в свою очередь, потребовалось создание собственной ремонтно-технической базы. В г. Владивосток завод «Металлист», выпускавший ранее различные крупногабаритные устройства из металла, в 1935 г. приступил к освоению производства горных механизмов для треста «Дальтрансуголь». Предприятие начало производить шахтовые клети, опрокиды, скипы, копровые шкивы, копры. За первый год работы оно изготовило 250 штук шахтовых вагонеток. В последующие годы на заводе «Металлист» установили специализированные станки и аппараты, что позволило выполнять более сложные заказы на изготовление ленточных и пластинчатых транспортеров, механических грузчиков, буров «Батурина», лебедок колонковых, приводов для качающихся конвейеров «ДК-15» и «ДК-5», вентиляторов «Сирокко» и другой техники. Наличие местного завода горных механизмов и оборудования отчасти снизило зависимость угольных предприятий
Приморья от поставок из центральных районов (ГАПК. Ф. Р-498. Оп. 2. Д. 64. Л. 50а, 95об.).

Для выполнения текущих ремонтных работ при управлениях Сучанских и Артемовских копей на базе старых механических мастерских создали центральные электромеханические мастерские (ЦЭММы), которые оснастили различными металлообрабатывающими станками, прессами, аппаратами. ЦЭММы представляли собой «мини-заводы», не только выполняющие ремонт моторов, электротехники, механизмов, но и изготавливающие необходимые детали и части для шахтового оборудования (РГАЭ. Ф. 1562. Оп. 313. Д. 157. Л. 79, 93, 95).

Итак, в результате технического прогресса и переоснащения приморских шахт во второй пятилетке значительно вырос уровень механизированной добычи угля. Если в 1932 г. только 2/5 угля в тресте «Дальтрансуголь» добывалось при помощи машин и механизмов, то в 1937 г. свыше 4/5. Уровень механизации в 1931 г. по тресту достигал 32,3\%, в 1937 г. - уже 76,8\%. Высокой степенью механизации отличались новые построенные крупные шахты № 20 на Сучане и № 3-ц в Артеме, где доля добываемого таким способом угля в 1937 г. составляла 87,7\%. Здесь с 1938 г. уже внедряли полный цикл механизации, предусматривающий как разрубку, так и доставку угля до подъемника с применением различных механизмов и машин (ГАПК. Ф. Р-1197. Оп. 1 Д. 4 Л. 68, 68а; Ф. Р-498. Оп. 2. Д. 133. Л. 102). По основным машинам и механизмам приморские шахты к 1939 г. были обеспечены уже на 100\% (см. табл. 1).

Фактором, обеспечившим усиление механизации труда и подъем культурно-технического уровня рабочих угольной отрасли Приморья, стало стахановское движение, активно развернувшееся в конце 1935-1938 гг. на шахтах Сучана, Артема и Тавричанки. В тресте «Дальтрансуголь» к середине 1930-х гг. сформировались условия для возникновения и развития движения новаторов, улучшалось техническое нормирование и организация труда, произошла ломка старых норм выработки, был существенно повышен уровень заработной платы, внедрена более эффективная система ведения работы в забоях.

Рекорд А.Г. Стаханова благодаря широкой государственной пропаганде быстро превратился в массовое движение, охватившее угольную промышленность страны. На Сучане 22 сентября 1935 г. за 6 часов смены забойщик Е.Е. Ко- 
Техническая оснащенность угольных предприятий Приморья, 1939 г.

\begin{tabular}{|l|c|c|c|}
\hline \multicolumn{1}{|c|}{ Машины и механизмы } & В наличии, ед. & Фактически в работе, ед. & Обеспеченность, \% \\
\hline Врубовые машины & 16 & 8 & 100 \\
\hline Отбойные молотки & 609 & 402 & 100 \\
\hline Электробуры ручные & 203 & 200 & 100 \\
\hline Электровозы & 15 & 10 & 80 \\
\hline Компрессоры стационарные & 8 & - & 100 \\
\hline Компрессоры передвижные & 8 & 13 & 100 \\
\hline Лебедки двухбарабанные & 16 & 6 & 400 \\
\hline Лебедки однобарабанные & 24 & 68 & 98 \\
\hline Вентиляторы & 68 & 84 & 151 \\
\hline Насосы центробежные & 127 & & \\
\hline
\end{tabular}

Источники: ГАПК. Ф. Р-498. ОП. 2. Д. 218. Л. 33; Ф. П-68. Оп. 4. Д. 67. Л. 45.

робейников вырубил 84,5 т угля, тем самым перевыполнив норму на $685 \%$. Опыт движения за высокие показатели в труде на шахтах Сучана получил широкое признание и быстрое развитие (см. табл. 2). По итогам четвертого квартала 1935 г. в стахановское движение предприятий треста «Дальтрансуголь» было вовлечено 639 человек или $9,1 \%$ от общего числа работников шахт. При этом рост производительности труда за этот период по тресту составил $11 \%$ (ГАПК. Ф. Р-498. Оп. 2. Д. 64. 32, 32об., 33).

Бюро Далькрайкома ВКП(б) сразу взяло под свой строгий контроль развитие стахановского движения в регионе, принимая различные организационные меры по его оформлению и закреплению. Сучанский горком ВКП(б) проделал большую работу по проведению в ноябре 1935 г. первого слета шахтеров-стахановцев Дальневосточного края. Слет обсудил методы работы и подвел итоги деятельности стахановцев. Отдельно обсуждались и факторы, тормозившие внедрение новых примеров работы в производство в Приморье, которые, по мнению участников слета, сводились исключительно к нежеланию руководителей и коллективов шахт работать по-стахановски (РГАСПИ. Ф. 17. Оп. 21. Д. 3650. Л. 150).

Одним из основных направлений деятельности новаторов стала борьба за повышение технической грамотности работников угольных предприятий. С 1936 г. началась перестройка системы учебной подготовки рабочих кадров шахт. 15 мая 1936 г. трест «Дальтрансуголь» создал штат инструкторов по внедрению стахановских методов работы. Также организовывались специальные курсы технического минимума, через которые только за 1936 г. прошло 4925 работников треста, из них 796 стахановцев. В числе трудностей, с которыми столкнулся трест в ходе повышения технической грамотности рабочих, оказалась острая нехватка учебных помещений и материалов для обучения. Со стороны шахтеров также нередко отмечалось нежелание проходить курсы техминимума (ГАПК. Ф. Р-498. ОП. 2. Д. 83. Л. 50об., 112об., 113).

Следует отметить, что стахановские методы ведения работы в условиях приморских шахт нередко приводили к повышению травматизма работников, а иногда - к трагедиям и гибели людей. Только за первое полугодие 1936 г. на Сучане произошло 6 смертельных случаев, получено 16 тяжелых и 551 легких травм. 27 июня 1937 г. на шахте № 20 произошел взрыв метана, погибло 3 стахановца, было разрушено 200 м штрека. После этого забойщики, проходчики и крепильщики категорически отказывались вести работы скоростными методами, без должного обеспе- 
Динамика стахановского движения на предприятиях угольной промышленности Приморья, 1935-1938 гг.

\begin{tabular}{|l|c|c|c|}
\hline \multirow{2}{*}{ Период } & \multicolumn{3}{|c|}{ Число стахановцев, чел. } \\
\cline { 2 - 4 } & Сучан & Артем & Трест «Дальтрансуголь» \\
\hline Декабрь 1935 г. & 367 & 167 & 639 \\
\hline Январь 1936 г. & 441 & 261 & 942 \\
\hline Декабрь 1936 г. & 310 & 500 & 1138 \\
\hline Январь 1937 г. & 358 & 565 & 1197 \\
\hline Декабрь 1937 г. & 442 & 546 & 1352 \\
\hline Январь 1938 г. & 592 & 506 & 1717 \\
\hline Декабрь 1938 г. & 572 & 1145 & \\
\hline
\end{tabular}

Источники: ГАПК. Ф. Р-498. Оп. 2. Д. 64. Л. 31об., 32, 33; Д. 83. Л. 49; Д. 135. Л. 50об.; Д. 170. Л. 34.

чения горно-подготовительных работ. С июля по сентябрь 1937 г. число работников шахты, работающих по-стахановски и участвующих в социалистическом соревновании, сократилось с 20 до 10,8\%. Развертывание стахановского движения послужило и началу кампании по поиску вредителей и саботажников на приморских шахтах. Частые поломки механизмов и прибывшей из центральных регионов техники, случавшиеся и раньше, теперь служили обычным поводом для обвинений в адрес инженерно-технических работников и руководства шахт (РГАСПИ. Ф. 17. Оп. 21. Д. 3651. Л. 135).

Стахановское движение давало лишь отдельные рекорды и начиная с 1937 г. уже слабо влияло на общую производительность труда. В 1938 г. из всего числа стахановцев шахт Приморья только пять человек регулярно выполняли нормы на 150-200\%, остальных же искусственно записывали в стахановцы для статистики и отражения в отчетах их количественного роста. При этом само руководство шахт не придавало значение правильной организации движения, стахановцы были предоставлены сами себе. Так, в бригадах не был разделен труд, отсутствовали точные графики организации труда и т.д. (ГАПК. Ф. Р-498. Оп. 2. Д. 170. Л. 34об., 52об.).

Важную роль в техническом прогрессе и повышении технического уровня организации работ приморских шахт сыграли инженерно-технические работники. Они внесли значительное количество предложений по механизации и рационализации производства с учетом специфики местных шахт. Так, благодаря этим предложениям кардинально изменилась работа угольных предприятий Артема. Здесь во второй пятилетке внедрили новый тип лопат навалки угля для передачи двум конвейерным линиям, расположенным под углом, применили угловую колонку, разработали автоматический сигнал для установки бесконечного каната, предотвращающий возможность сбрасывания каната с натяжного шкива. Эти и другие мероприятия позволили значительно увеличить добычу угля на шахтах Артема (ГАПК. Ф. Р-498. Оп. 2. Д. 83 Л. 2, 51об.).

Продуктивность по результатам усиления механизации и стахановского движения на угольных предприятиях Приморья не оправдывала ожиданий дальневосточных партийно-хозяйственных и центральных органов власти. На шахты неоднократно направлялись различные комиссии для выяснения причин слабого использования техники и препятствий внедрения стахановских методов работы, срывов плановых заданий.

В июне 1938 г. на заседании Далькрайкома ВКП(б) докладывалось о результатах проверки 
Динамика добычи угля на шахтах Сучана и Артема, 1932-1936 гг.

\begin{tabular}{|c|c|c|}
\hline \multirow{2}{*}{ Годы } & \multicolumn{2}{|c|}{ Добыто угля, тонн } \\
\cline { 2 - 3 } & Сучан & Артем \\
\hline 1932 & - & 1126175 \\
\hline 1933 & 376000 & 1416700 \\
\hline 1934 & 503400 & 1680100 \\
\hline 1935 & 560000 & 1922000 \\
\hline 1936 & 765900 & 2362800 \\
\hline
\end{tabular}

Источники: ГАПК. Ф. Р-1197. Оп. 1. Д. 4. Л. 211; Д. 8. Л. 35; Ф. Р-498. Оп. 2. Д. 16. Л. 6; Д. 64. Л. 2; Д. 83. Л. 2; Д. 133. Л. 102.

работы Сучанских, Артемовских и Тавричанских шахт, в ходе которой было выявлено значительное количество проблем. Большая часть машин и техники в первом полугодии 1938 г. простаивала, на шахтах Сучана работала только треть машин. Врубовыми машинами добывалось менее $15 \%$ угля, половину машин не включали в работу вовсе. Компрессоры использовались неэффективно, из-за постоянных перебоев в электроэнергии на шахтах Сучана отключались насосы, происходило их затопление, в результате в сутки не додавалось в среднем 500 т угля. Артемовская ГРЭС работала с большими перебоями, выдавая шахтам всего по 5-6 тыс. кВт вместо положенных 15-16 тыс. кВт мощности. На Артемовских шахтах распространялись антимеханизаторские настроения, на крупнейшей шахте № 3-ц все до одного забойщика отказывались работать по-стахановски. На шахтах Тавричанки для 250 стахановцев не были подготовлены условия труда. Серьезной и годами не решаемой проблемой оставался острый дефицит жилья. Так, на одного сучанского шахтера, в том числе стахановца, приходилось всего 3,5 м $^{2}$ жилой площади. На самой крупной шахте № 20 Сучана, которая располагалась в 7 км от центра города, не имелось ни одного магазина и лавки, где можно было купить мясо и рыбу, a снабжение овощами этого района находилось на низком уровне. На шахте отсутствовала баня, что в условиях тяжелого подземного труда шахтеров являлось недопустимым. Шахтеры отказывались работать по-стахановски (РГАСПИ. Ф. 17. ОП. 21. Д. 3629. Л. 110, 114, 113, 36; Д. 3651. Л. 129).
Выявляемые недоставки привели в конечном итоге к реорганизации треста «Дальтрансуголь», к поиску виноватых и репрессиям в 1937-1938 гг. Этот вопрос требует отдельного рассмотрения. Отметим здесь, что партийно-хозяйственные и следственные органы не учитывали всех объективных условий и трудностей, в которых оказались и развивались приморские шахты. Все неполадки и проблемы объяснялись вредительством, хотя такие факты действительно имели место и были связаны с низкой квалификацией и трудовой дисциплиной самих рабочих.

Несмотря на все трудности, в деле механизации и развития угольной отрасли Приморья имелись определенные успехи. За годы второй пятилетки добыча угля в Приморье выросла в 1,9 раза - с 1623 тыс. т до 3153 тыс. т, при этом по Артему - в 2 раза (см. табл. 3). Однако значительный рост добычи не смог покрыть потребность региона в минеральном топливе (только на $82 \%$ ), индустриальное и оборонное строительство требовало значительно большее его количество. С 1937 г. уголь дополнительно начал завозиться в регион из Кузбасса [14, с. 28].

За годы индустриализации произошли качественные изменения в шахтерском труде, постепенно отмирали старые профессии, основанные на ручном труде, на смену им приходили новые. К середине 1930-х гг. в штатных расписаниях приморских шахт числились машинисты врубовых машин, машинисты электровозов, машинисты конвейеров и транспортеров, забойщики на отбойных молотках, бурильщики, переносчики конвейеров, элек- 
трослесари, горные электромеханики, лебедочники и другие специалисты. Среди них еще оставались профессии тяжелого ручного труда, но их доля постепенно сокращалась.

Таким образом, в годы индустриализации произошла глубокая техническая реконструкция угольных предприятий Приморья, изменившая структуру и технологическую организации угледобывающего производства. На смену полукустарным дореволюционным шахтам, основанным на ручном труде и паровых машинах, пришли современные технически оснащенные механизированные угледобывающие предприятия, работающие на машинах с электрическим приводом. На начальном этапе технического перевооружения отрасли важную роль сыграли импортные поставки машин. Процесс технического переоснащения шахт Приморья происходил в условиях их оторванности от крупнейших угледобывающих баз и машиностроительных заводов страны, ограниченности финансовых, материальных и трудовых ресурсов, острого дефицита электроэнергии, слабости собственной ремонтно-технической базы, сложности геологического строения угольных месторождений. В результате освоение новой техники происходило здесь медленнее, чем, например, на предприятиях Сибири, а процессы технической перестройки в регионе в довоенный период так и не были завершены. Тем не менее, приморские шахты в годы индустриализации стали главной топливной базой для развития электроэнергетики, индустрии и оборонной промышленности Дальнего Востока.

\section{СПИСОК ЛИТЕРАТУРЫ}

1. Борисов Ю.Б. Технический прогресс в механизации труда шахтеров // Уголь Приморья. Материалы научно-практической конференции, посвященной 125-летию промышленной разработки угля в Приморском крае. 27-28 августа 1993 г., Владивосток. Владивосток, 1993. C. 199-205.

2. Буткин Н.А. Угольная промышленность Приморья в предвоенные и военные годы // Уголь Приморья. Материалы научно-практической конференции, посвященной 125-летию промышленной разработки угля в Приморском крае. 27-28 августа 1993 г., Владивосток. Владивосток, 1993. С. 97-113.

3. Быструшкин А.Ю. Государственная политика и частный капитал в сфере развития угольной промышленности на Дальнем Востоке во второй половине XIX - 20-е гг. XX в.: дисс. ... канд. ист. н. Комсомольск-на-Амуре, 2010.

4. Глущенко И.И. Рабочий класс советского Дальнего Востока в переходный к социализму период (1922-1937). Владивосток: Изд-во Дальневост. ун-та, 1986.

5. Дальний Восток России в эпоху советской модернизации: 1922 - начало 1941 года / Отв. ред. Л.И. Галлямова. Владивосток: Дальнаука, 2018.

6. Деревянко А.П. Угольная промышленность Приморья. Страницы истории // Уголь Приморья. Материалы научно-практической конференции, посвященной 125-летию промышленной разработки угля в Приморском крае. 27-28 августа 1993 г., Владивосток. Владивосток, 1993. С. 20-72.

7. Деревянко А.П. Соревнование в угольной промышленности Приморья и его роль в повышении производительности труда (30-е - середина 80-х годов) // Угольная промышленность Приморья (история, состояние и перспективы развития). Владивосток, 1993. С. 196-248.

8. Ермакова Э.В. Угольщики Приморья в 20-е - начало 30-х годов // Угольная промышленность Приморья (история, состояние и перспективы развития). Владивосток, 1993. C. 80-92.

9. Маклюков А.В. Электрификация российского Дальнего Востока (конец XIX - середина XX вв.). Владивосток: Изд-во ДВФУ, 2016.

10. Мишустин Д.Д. Внешняя торговля и индустриализация СССР. М.: Международная книга, 1938.

11. Самигулин Р.М. Сучанский рудник (конец 19 века - 1915 год) // Угольная промышленность Приморья (история, состояние и перспективы развития). Владивосток, 1993. С. 132-137.

12. Тарасова Ю.А. К вопросу о социалистической индустриализации Дальнего Востока в годы первой пятилетки // Дальний Восток за 40 лет Советской власти. Комсомольск-на-Амуpe, 1958. С. 112-120.

13. Тютяева М.В. История формирования и развития угольной промышленности Сахалина (середина XIX - 1945 г.): дисс. ... канд. ист. н. Южно-Сахалинск, 2013.

14. Угольная промышленность Приморья. Владивосток: Изд-во ТАНЭБ, 1997.

15. Унпелев Г.А. Завершение социалистической реконструкции промышленности Дальнего Востока (1933-1937 гг.). О деятельности Коммунистической партии по социалистической 
индустриализации Дальневосточного края. Владивосток: Дальневост. кн. изд-во, 1975.

16. Унпелев Г.А. Социалистическая индустриализация Дальнего Востока. О деятельности Коммунистической партии по индустриализации Дальневосточного края 1928-1932 гг.). Владивосток: Дальневост. кн. изд-во, 1972.

\section{REFERENCES}

1. Borisov, Yu.B., 1993. Tekhnicheskii progress v mekhanizatsii truda shakhterov [Technological progress in the mechanization of miners' labor]. In: Ugol' Primor'ya. Materialy nauchno-prakticheskoi konferentsii, posvyashchennoi 125-letiyu promyshlennoi razrabotki uglya v Primorskom krae. 27-28 avgusta 1993 g., Vladivostok. Vladivostok, 1993, pp. 199-205. (in Russ.)

2. Butkin, N.A., 1993. Ugol'naya promyshlennost' Primor'ya v predvoennye i voennye gody [Coal industry of Primorye in the prewar years and during war]. In: Ugol' Primor'ya. Materialy nauchno-prakticheskoi konferentsii, posvyashchennoi 125-letiyu promyshlennoi razrabotki uglya $\mathrm{V}$ Primorskom krae. 27-28 avgusta 1993 g., Vladivostok. Vladivostok, 1993, pp. 97-113. (in Russ.)

3. Bystrushkin, A.Yu., 2010. Gosudarstvennaya politika i chastnyi kapital v sfere razvitiya ugol'noi promyshlennosti na Dal'nem Vostoke vo vtoroi polovine XIX - 20-e gg. XX v. [State policy and private capital in the development of the coal industry in the Russian Far East, late XIXth century 1920s], dissertatsiya kandidata istoricheskikh nauk. Komsomol'sk-na-Amure. (in Russ.)

4. Glushchenko, I.I., 1986. Rabochii klass sovetskogo Dal'nego Vostoka v perekhodnyi k sotsializmu period (1922-1937) [The working class of the Soviet Far East in the period of transition to socialism, 1922-1937]. Vladivostok: Izd-vo Dal'nevost. un-ta. (in Russ.)

5. Gallyamova, L.I. ed., 2018. Dal'nii Vostok Rossii v epokhu sovetskoi modernizatsii: 1922 nachalo 1941 goda [Russian Far East in the era of Soviet modernization, 1922 - early 1941]. Vladivostok: Dal'nauka. (in Russ.)

6. Derevyanko, A.P., 1993. Ugol'naya promyshlennost' Primor'ya. Stranitsy istorii [Coal industry of Primorye: the pages of history]. In: Ugol' Primor'ya. Materialy nauchno-prakticheskoi konferentsii, posvyashchennoi 125-letiyu promyshlennoi razrabotki uglya $\mathrm{v}$ Primorskom krae. 27-28 avgusta 1993 g., Vladivostok. Vladivostok, 1993, pp. 20-72. (in Russ.)
7. Derevyanko, A.P., 1993. Sorevnovanie v ugol'noi promyshlennosti Primor'ya i ego rol' v povyshenii proizvoditel'nosti truda (30-e seredina $80-\mathrm{kh}$ godov) [Competition in the coal industry of Primorye and its role in increasing labor productivity, 1930s - mid-1980s]. In: Ugol'naya promyshlennost' Primor'ya (istoriya, sostoyanie i perspektivy razvitiya). Vladivostok, 1993, pp. 196-248. (in Russ.)

8. Ermakova, E.V., 1993. Ugol'shchiki Primor'ya v 20-e - nachalo 30-kh godov [Coal miners of Primorye in the 1920s and early 1930s]. In: Ugol'naya promyshlennost' Primor'ya (istoriya, sostoyanie i perspektivy razvitiya). Vladivostok, 1993, pp. 80-92. (in Russ.)

9. Maklyukov, A.V., 2016. Elektrifikatsiya rossiiskogo Dal'nego Vostoka (konets XIX seredina XX vv.) [Electrification of the Russian Far East (late XIXth - mid-XXth century)]. Vladivostok: Izd-vo DVFU. (in Russ.)

10. Mishustin, D.D., 1938. Vneshnyaya torgovlya i industrializatsiya SSSR [Foreign trade and industrialization of the USSR]. Moskva: Mezhdunarodnaya kniga. (in Russ.)

11. Samigulin, R.M., 1993. Suchanskii rudnik (konets 19 veka - 1915 god) [Suchan mines, late XIXth century - 1915)]. In: Ugol'naya promyshlennost' Primor'ya (istoriya, sostoyanie i perspektivy razvitiya). Vladivostok, 1993, pp. 132-137. (in Russ.)

12. Tarasova, Yu.A., 1958. K voprosu o sotsialisticheskoi industrializatsii Dal'nego Vostoka $\mathrm{v}$ gody pervoi pyatiletki [To the issue of the socialist industrialization of the Russian Far East during the first five-year plan]. In: Dal'nii Vostok za 40 let Sovetskoi vlasti. Komsomol'skna-Amure, 1958, pp. 112-120. (in Russ.)

13. Tyutyaeva, M.V., 2013. Istoriya formirovaniya i razvitiya ugol'noi promyshlennosti Sakhalina (seredina XIX - 1945 g.) [The history of the formation and development of the coal industry in Sakhalin, mid-XIXth century - 1945], dissertatsiya kandidata istoricheskikh nauk. Yuzhno-Sakhalinsk, 2013.

14. Ugol'naya promyshlennost' Primor'ya [Coal industry of Primorye]. Vladivostok: Izd-vo TANEB, 1997. (in Russ.)

15. Unpelev, G.A., 1975. Zavershenie sotsialisticheskoi rekonstruktsii promyshlennosti Dal'nego Vostoka (1933-1937 gg.). O deyatel'nosti Kommunisticheskoi partii po sotsialisticheskoi industrializatsii Dal'nevostochnogo kraya [Finalization of the socialist reconstruction of the 
industry in the Russian Far East, 1933-1937. On the efforts of the Communist Party to promote socialist industrialization of the Far Eastern Territory]. Vladivostok: Dal'nevost. kn. izd-vo. (in Russ.)

16. Unpelev, G.A., 1972. Sotsialisticheskaya industrializatsiya Dal'nego Vostoka. O deyatel'- nosti Kommunisticheskoi partii po industrializatsii Dal'nevostochnogo kraya 1928-1932 gg.) [Socialist industrialization of the Russian Far East. On the efforts of the Communist Party to promote the industrialization of the Far Eastern Territory, 1928-1932)]. Vladivostok: Dal'nevost. kn. izd-vo. (in Russ.)

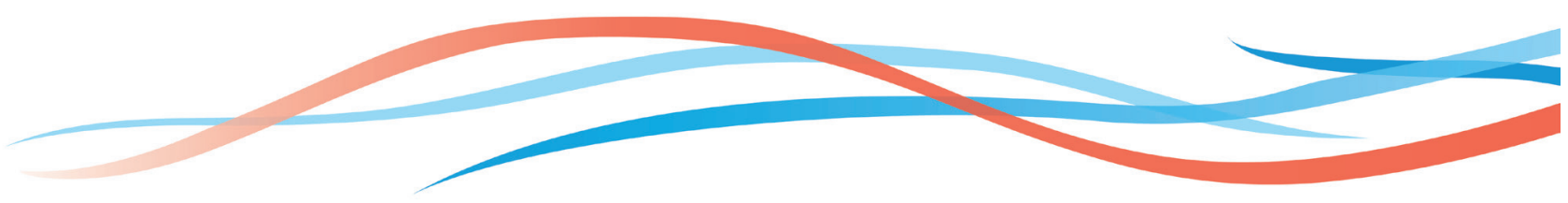

